\author{
Marek Jędraszewski \\ Uniwersytet im. Adama Mickiewicza w Poznaniu \\ abp.marek@archidiecezja.lodz.pl
}

\title{
UWIECZNIAĆ SIĘ JAKO GATUNEK LUDZKI
}

\section{Rémi Brague jako humanista}

„Jestem Francuzem, katolikiem, filozofem z wykształcenia, nauczycielem akademickim z zawodu" - pisze o sobie Rémi Brague w dziele, którym zasłynął na całym świecie - opublikowanej w 1992 roku książce Europe, la voie romaine, czyli Europa, droga rzymska1. Dodaje przy tym: "Jako Europejczyk piszący o Europie jestem uczestnikiem tego, o czym piszę"2.

Tym samym autor wyraźnie wskazuje na to, że jest uczestnikiem pewnej, bardzo określonej, rzymskiej drogi, którą jako Francuz, urodzony w Paryżu w 1947 roku, kroczy już prawie siedemdziesiąt lat. Nie kroczy nią sam w jego życiu rodzinnym na tej drodze towarzyszy mu od wielu lat żona, później dołączyło czworo dzieci urodzonych między 1972 a 1983 rokiem, na koniec dwoje wnucząt. Będąc filozofem, a równocześnie katolikiem, łączy w sobie owo szczególne napięcie między Atenami a Jerozolimą, które stanowiło i ciągle jeszcze stanowi o wyjątkowości i oryginalności kultury i cywilizacji europejskiej. Z ducha Rzymianin, zatem człowiek duchowo otwarty również na inny w stosunku do swojego świat, studiował zarówno język hebrajski, przez co dał się poznać jako znakomity znawca judaizmu, jak i arabski, dzięki czemu dogłębnie poznał islam. Profesor licznych uniwersytetów europejskich i amerykańskich, zasłynął przede wszystkim jako wykładowca na Sorbonie (l'Université Panthéon-Sorbonne, Paris I) w latach

\footnotetext{
${ }^{1}$ R. Brague, Europa, droga rzymska, tłum. W. Dłuski, Warszawa 2012, s. 218.

2 Ibidem.
} 
1990-2010 oraz Monachijskiego Ludwig-Maximilians-Universität, gdzie w latach 2002-2013 był profesorem „für Religionswissenschaft unter besonderer Berücksichtigung der europäischen Religionsgeschichte und der christlichen Weltanschauung", przedłużając dzieje słynnej katedry Romano Guardiniego. $W$ ten sposób wyznaczał intelektualną i duchową drogę dla ogromnej rzeszy studentów, a także czytelników swych dzieł. Rémi Brague jest bowiem autorem prawie dwudziestu książek, tłumaczonych na wiele języków, oraz około stu dwudziestu artykułów, publikowanych w czasopismach naukowych lub dziełach zbiorowych.

\section{Uwiecznianie jako problem filozoficzny}

Pytanie postawione Rémiemu Braguéowi przez Rogera-Pola Droita: „W imię czego należy się uwieczniać?”3, trafia nie tylko w żywe zainteresowania naszego "filozofa drogi” i nie tylko w problematykę jego wydanej niedawno książki Les ancres dans le ciel (Kotwice nieba); trafia bowiem też $\mathrm{w}$ fundamentalny problem filozofii: jak się utrwalić, jak się uwiecznić jako gatunek ludzki - zatem w problem przeżycia ludzkości w ogóle, niepodejmowany jednakże $w$ filozofii współczesnej. Ta bowiem bardziej zajmuje się sprawą koegzystencji międzyludzkiej niż samymi warunkami istnienia człowieka jako takiego. Można jednak wskazać filozofa, któremu ta kwestia nie jest obca.

Emmanuel Lévinas - będący, podobnie jak Brague, filozofem drogi i syntetyzującej myśli o Europie, wyrażonej esencjonalnie w przekonaniu: „Europa to Biblia i Grecy” - w różnych aspektach rozważa problem uwieczniania. W Całości i nieskończoności na przykład pisze:

Spotkanie Innego pod postacią kobiety pozwala nadejść - ponad możliwością i projektem - przyszłości w postaci dziecka. [...] Moja przyszłość - jednocześnie moja i nie moja, stanowiąca możliwość mnie samego, ale również możliwość Innego, Ukochanej - nie mieści się w logicznej istocie możliwości. Relację z taką przyszłością niesprowadzalną do władzy, jaką mam nad możliwościami - nazywamy płodzeniem $^{4}$.

${ }^{3}$ Jest to pytanie Rogera-Pola Droita: „Au nom de quoi faut-il se perpétuer?” skierowane do Remi Brague'a po ukazaniu się jego książki Les ancres dans le ciel. L'infrastructure métaphysique, Paris 2011. http://www.lepoint.fr/culture/au-nom-de-quoi-faut-il-se-perpetuer-21-042011-1323373_3.php [dostęp: 22.06.2016 r.].

${ }^{4}$ E. Lévinas, Całość i nieskończoność, tłum. M. Kowalska, Warszawa 1998, s. 323. 
To wykraczanie poza logiczną istotę możliwości, będącej rdzeniem racjonalistycznego myślenia, ukierunkowuje refleksję Lévinasa na filozofię spotkania, budowaną na logice pragnienia - logice przekraczającej rozumowe standardy wyjaśniania i podążającej w stronę nadziei na realizację dobra, wartości będącej życiową busolą. Ta busola orientuje nie tylko na Drugiego, pojmowanego dialogicznie - jako odniesienie usensawniające moje życie, ale i na przyszłość, która wymyka się mojemu władaniu. Orientuje na nadzieję, w którą wpisany jest Inny jako dziecko - byt osobowy ze mną złączony i mnie przekraczający. Byt, który gwarantuje ludzkie istnienie w ogóle.

To, co wykracza poza substancje - pisze Lévinas - nie jest dane mojej władzy i nie potwierdza mojego Ja. [...] Jest przyszłością, która odnosi się jeszcze do bytu osobowego, choć zarazem się z niego wyzwala: dzieckiem, w pewnym sensie moim, a dokładniej - w pewnym się będącym mną, ale nie mną samym, dzieckiem, które nie zapada się w moją przeszłość, nie spaja się z nią, by złożyć się na moje życie ${ }^{5}$.

Lévinasowską filozofię pragnienia można spointować stwierdzeniem o konieczności przekraczania siebie w kierunku uwieczniania się istnienia jako takiego - jako przedłużania ludzkiego gatunku.

Te rozważania można skojarzyć też z obcą na pierwszy rzut oka myślą Pascala czy Kierkegaarda, wyrażoną w metaforze życia ludzkiego jako przebywania na pływającym po morzu statku. Obaj filozofowie wyrażają przez nią poczucie zagubienia i zagrożenia osoby (w szczególności wierzącego chrześcijanina), która musi konfrontować się z wielkością i nieprzewidywalnością świata - tak jak na statku konfrontujemy się z zagrażającym sztormem i pozostajemy jedynie pasażerami, poddając się wydarzeniom i przypadkom.

Zarówno jednak dla Kierkegaarda, jak i Pascala, logika pragnienia i wartość dobra organizują indywidualne życie w odniesieniu do dawcy życia w ogóle, dawcy, który umożliwia transcendowanie siebie, bowiem: „Miło znajdować się na statku smaganym burzą, kiedy się ma pewność, że się nie zginie" $^{\prime \prime}$. Tę pewność daje właśnie sterowanie w kierunku Boga.

W filozoficzną refleksję Pascala i Kierkegaarda, ewokowaną metaforą życia jako statku na morzu, włączyć można też wiele egzystencjalnych prawd i ich egzystencjalistycznych konceptualizacji obecnych u Alberta Camusa. Szczególnie jego pytanie: „Czy życie warte jest trudu, aby je przeżyć?"7, regularnie pojawiające się, niczym refren, w jego twórczości literac-

${ }^{5}$ Ibidem, s. 328-329.

${ }^{6}$ B. Pascal, Myśli, tłum. T. Żeleński (Boy), Warszawa 1977, s. 329.

7 Przede wszystkim w: A. Camus, Mit Syzyfa, w: idem, Mit Syzyfa. Dwa eseje, tłum. J. Guze, Warszawa 1991. 
kiej i filozoficznej, podejmuje kwestię międzyludzkich relacji; kwestię wnikliwie, co prawda, opisywaną, lecz z reguły z pesymistyczną ich wykładnią, nakazującą niejako zwątpienie $\mathrm{w}$ sens życia. Udzielając odpowiedzi na to zasadnicze pytanie, proponując jednostce, jako rozwiązanie, tragiczny bunt przeciwko absurdowi, Camus nie podejmuje jednak problemu istnienia jako takiego.

Zauważmy, że wszystkie przywołane nazwiska uznanych filozofów, etykietujące nurt myślenia egzystencjalistycznego, nie firmują rozważań, które narzucają się przy podejmowanym przez nich zagadnieniu istnienia ludzkiego en general. Natomiast pytanie zadane Brague'owi nie dotyczy nas jako jednostek, lecz przedłużenia gatunku ludzkiego, do którego należymy. Odpowiedź na nie udzielona, którą uprzedzająco można już zarysować, brzmi: żeby przedłużyć gatunek ludzki, trzeba optować za prokreacją, trzeba po prostu mieć dzieci. I to jest dzisiaj problemem - nie tylko socjologicznym, politycznym czy demograficznym, lecz także filozoficznym, dokładniej - metafizycznym, od którego uciekamy, mówiąc o „zwijaniu metafizyki”, zauroczeni, na przykład, myślą Martina Heideggera, ale od którego tak naprawdę ucieczki nie ma ani w bankrutującej humanistyce, ani tym bardziej w życiü

\section{Zwątpienie w sens a prawo przekazywania życia}

Zarysowany kontekst filozoficzny pozwala już na postawienie pytania o możliwość rozwikłania pojawiającej się paradoksalnej sytuacji przekonaniowej i egzystencjalnej zarazem. Bo na mocy prawa prokreacji, jeśli problematyczne jest danie racji, aby żyć, to bezwzględnie musimy posiadać racje, aby dać komuś życie.

Aby tę paradoksalność zrozumieć, wystarczy odwołać się do Alexandra von Humboldta (1769-1859), nie tylko cenionego geografa, lecz uznanego autorytetu humanistycznego, który pisał: „Uważam, że małżeństwo jest grzechem, a prokreacja dziecka jest zbrodnią. [...] Jestem również przekonany, że ten, kto poddaje się małżeńskiemu jarzmu, jest głupim, a nawet grzesznikiem. [...]. Jest grzesznikiem, ponieważ daje życie dzieciom, nie

${ }^{8}$ Wystarczy w tej kwestii przywołać diagnozy L. Kołakowskiego czy B. Skargi; zob. L. Kołakowski, Wielka Mała Encyklika, w: idem, Jezus ośmieszony. Esej apologetyczny i sceptyczny, tłum. D. Zańko, Kraków 2014; B. Skarga, Sceptycyzm metafizyka podszyty, "Tygodnik Powszechny" 2002, nr 12; eadem, Kilka słów w obronie metafizyki, „Archiwum Historii Filozofii i Myśli Społecznej" 1991, nr 36. 
mogąc im dać pewności szczęścia" ${ }^{9}$. Równie drastycznie brzmią niektóre stwierdzenia Gustawa Flauberta, dziewiętnastowiecznego pisarza, jak na przykład to: „Nikomu nie przekażę nudności i hańby istnienia” 10.

Na tle przywołanych wypowiedzi nie szokują już deklaracje Davida Benatara (ur. 1966), profesora filozofii w Południowej Afryce, który twierdzi, iż nie tylko nie mamy prawa siebie reprodukować, ale mamy nawet obowiązek tego nie czynić - jesteśmy moralnie zobowiązani, aby postawić kropkę na przygodzie ludzkiej. Dobrowolne zniknięcie ludzkości byłoby nawet w interesie tych, którzy mogliby się narodzić; nie ma żadnego argumentu na rzecz dalszego istnienia ludzkości.

W podobnym duchu wypowiada się Richard Rorty (1931-2007), amerykański profesor filozofii i literaturoznawstwa porównawczego, przedstawiciel neopragmatyzmu, formułując swój opis społeczeństwa totalnie pozbawionego odniesienia do boskości:

W swej postaci idealnej kultura liberalizmu byłaby na wskroś oświecona i świecka. Nie pozostałby w niej żaden ślad boskości, ani w formie ubóstwionego świata, ani też $\mathrm{w}$ formie ubóstwionej jaźni. W kulturze takiej nie byłoby miejsca na pogląd, że istnieją jakieś pozaludzkie moce, wobec których ludzie są odpowiedzialni. Porzuciłaby ona, bądź radykalnie zreinterpretowała, nie tylko ideę świętości, ale także idee „wierności prawdzie” i „zaspokojenia najgłębszych potrzeb ducha”. W idealnym modelu kulminacją procesu odbóstwienia [...] byłaby sytuacja, kiedy nie potrafilibyśmy już znaleźć żadnego zastosowania dla koncepcji mówiącej, że skończone, śmiertelne, przygodnie bytujące ludzkie istoty mogą czerpać sens swego życia z czegokolwiek różnego od innych, skończonych, śmiertelnych, przygodnie bytujących istot ludzkich ${ }^{11}$.

Emil Cioran (1911-1995), rumuński filozof, teoretyk nihilizmu i eseista piszący przede wszystkim w języku francuskim, dokonując rozrachunku ze swoim życiem, stwierdził, że przynajmniej nie popełnił tej zbrodni, iż zrodził dzieci:

Jedyną rzeczą, którą się chlubię, jest to, że zrozumiałem bardzo wcześnie, gdy miałem lat dwadzieścia, iż nie powinno się rodzić dzieci. Moja odraza do małżeństwa, do rodziny, do wszystkich konwencji społecznych, pochodzi właśnie z tego. Jest

${ }^{9}$ A. von Humboldt, ...aus dem Tagebuch der 1852 verstorbenen Gräfin von B., vorherigem Fräulein von R., darin sie ein Gespräch Humboldts, das er 1812 in Paris mit einem ihrer Freunde geführt hat, niederlegt, www.salmoxisbote.de/Bote06/Humboldt.htm [dostęp: 27.06.2016 r.]. Por. także: K. B. Biermann, Miscellanea Humboldtiana, Berlin, Akademie Verlag, 1990, s. 262.

${ }_{10}$ G. Flaubert, List do Louise Colet, 11 XI 1852, w: idem, Correspondance, Paris 1980, cyt. za: R. Brague, Les ancres..., op. cit., s. 91 (jeśli nie podano inaczej, tłumaczenia cytatów pochodzą od autora artykułu).

${ }^{11}$ R. Rorty, Przygodność, ironia i solidarność, tłum. W.J. Popowski, Warszawa 2009, s. 82-83. 
zbrodnią przekazywanie swych własnych ułomności potomstwu i zobowiązać je do przejścia przez te same doświadczenia jak wasze i do kalwarii być może jeszcze gorszej niż wasza. Nigdy nie mogłem się zgodzić, aby dać życie komuś, kto dziedziczyłby moje nieszczęścia i moje zła. Wszyscy rodzice to osoby nieodpowiedzialne lub zabójcy. Litość nie pozwala na to, aby się było rodzicem. Jest to słowo najbardziej okrutne, jakie znam ${ }^{12}$.

W kontekście przytoczonych wypowiedzi, stanowisko Brague'a rysuje się jako absolutnie odmienne. Brague dostrzega w nich ostateczne konsekwencje immanentnej logiki ateizmu, wyrażonej w przeświadczeniu, że mogę heroicznie zaakceptować istnienie, które zostało mi dane, ale czy mam prawo dać je drugiemu człowiekowi?

\section{Poza dobrem i złem}

Zauważmy, że pewne projekty, przedstawione w XVII wieku, obecnie znalazły techniczne możliwości ich realizacji.

Na ostatnie trzy wieki można spojrzeć według schematu trzech transcendentaliów i powiedzieć: wiek XIX był zdominowany przez problem Dobra, wiek XX przez problem Prawdy, natomiast wiek XXI miałby być zdominowany przez problem Bytu.

Wiek XIX problem Dobra wyraża poprzez podejmowanie kwestii socjalnych, problemów sprawiedliwości społecznej, teoretyzowaniu na temat proletariatu jako klasy wykluczonej czy kolonializmu.

Wiek XX drąży problem Prawdy w korelacji z jej przeciwnikami - Fałszem i Kłamstwem. W sukurs tym dociekaniom przychodzą reżimy ideologiczne (leninizm, nazizm), głoszące "prawdę naukową", forujące "naukowy światopogląd" i szukające uzasadnienia w XIX-wiecznym scjentyzmie. Zarówno nazizm, jak i leninizm opierają się na wiedzy traktowanej jako nauka (science) - pierwszy na nauce biologicznej, drugi na nauce socjologicznej i na marksistowskiej dialektyce odnoszącej się do historii układów społecznych (tak zwany materializm historyczny). Obydwie ideologie w swych fundamentalnych założeniach sytuują się nie na płaszczyźnie aksjologicznej - dobra i zła - lecz poznawczej - tego, co prawdziwe, i tego, co fałszywe - starając się przez ten manewr nadać sobie walor naukowy. Manewr ten wprowadza rażące zakłócenie epistemologiczne. Na logiczną opozycje prawdy i fałszu nakłada

12 E. Cioran, Cahiers 1957-1972, notatki między 11 a 12 XI 1962 r., Paris 1997, s. 125, cyt. za: R. Brague, Les ancres..., op. cit., s. 109-110. 
się porządek aksjologiczny i ideologiczny zarazem. Zakłócenie to skutkuje ukonstytuowaniem się w porządku quasi-naukowym wartości kłamstwa.

Stąd Sołżenicyn, demaskujący $\mathrm{w}$ swych powieściach ten mechanizm, stwierdza, że w czasach królowania ideologii marksistowskiej i komunistycznej największym cierpieniem było uczestniczenie $\mathrm{w}$ powszechnym kłamstwie, natomiast wyzwolenie $\mathrm{z}$ niego polegało na wydobyciu się $\mathrm{z}$ kłamstwa firmowanego naukowo.

\section{Inframoralna baza moralności}

E. Lévinas, mający świadomość możliwości tych aksjologiczno-epistemologicznych nadużyć, koncentruje się na rozważeniu raz jeszcze przedfilozoficznych uwarunkowań myśli i egzystencji ludzkiej. Dla niego pytanie „Być albo nie być?” nie jest pytaniem z gruntu ontologii fundamentalnej, której powrotu domagał się Heidegger. Wyprzedza je bowiem etyczny apel o nieuwarunkowaną rewindykację Dobra.

„Niezależność - napisze Lévinas - nie równa się idei causa sui, którą przekreśla zresztą fakt niewybranych i niewybieralnych własnych narodzin [la naissance non-choisie et impossible à choisir], rzucających wolę w świat anarchiczny, to znaczy pozbawiony początku"13. Fakt ten decyduje o niemożliwość autonomii człowieka, jeśli rozumieć ją jako możliwość stworzenia siebie przez siebie, i to on staje się wielkim dramat współczesnej myśli.

Torem odmiennym od Lévinasowskich rozważań biegnie myśl Hannah Arendt, która rozważa dramatyczność ludzkiego działania. Dostrzega w nim pewien paradoks związany z egzystencjalnymi wyborami dotyczącymi przedłużania swego istnienia. Jeśli bowiem przyjmujemy, że reprodukcja jest pierwszym warunkiem całego ludzkiego życia, że istnienie ludzkich bytów jest warunkiem pierwszym, koniecznym, chociaż nie wystarczającym, aby te byty zdecydowały się prowadzić życie w pełni ludzkie, nadając mu wymiar moralności („obowiązki wobec siebie”) - to wyrażenia te nie miałyby sensu, jeśli ludzie nie byliby podmiotami moralnymi i podmiotami prawa. Z drugiej jednak strony, nic nie pozwala nam myśleć, że istnieje obowiązek rodzenia dzieci - i na odwrót, że jest złem samym w sobie ich nie chciećc ${ }^{4}$.

Natomiast Hans Jonas dotyka idei obowiązku przedłużania ludzkiej historii i buduje ją na odpowiedzialności wobec „idei człowieka”, z której wy-

${ }^{13}$ E. Lévinas, op. cit., s. 199.

${ }^{14}$ H. Arendt, Kondycja ludzka, tłum. A. Łagocka, Warszawa 2016; eadem, Ludzie w mrocznych czasach, tłum. M. Godyń, Gdańsk 2013. 
nika "imperatyw ontologiczny”. To on stoi u podstaw pierwszej zasady „etyki przyszłościowości” (Zukünftigkeitsethik), która nie odnajduje się $\mathrm{w}$ etyce jako teorii działania, ale w metafizyce ${ }^{15}$. Zasada ta ewokuje intrygujące kwestie i jednocześnie sugeruje nań odpowiedzi: wobec kogo postępuję źle, jeśli nie chcę mieć dzieci? Z całą pewnością nie wobec tych dzieci, których nie chcę powołać do życia. Bowiem aby ludzkość mogła istnieć dalej, koniecznym jest, aby ludzie żywili ideę, że życie jest czymś dobrym. I jest to pogląd nie tylko tych, którzy dają życie, ale także tych, którzy je otrzymują. Pogląd ten, wpisany w etykę odpowiedzialności, H. Jonas uszczegóławia $\mathrm{w}$ "etyce rozwoju trwałego i zrównoważonego" wraz z "heurystyką strachu"16. To uszczegółowienie, wewnętrznie skonfliktowane, przywołuje pewną dominującą w Europie atmosferę światopoglądową, którą Jan Paweł II dobitnie określił jako „kulturę śmierci”. Zauważmy, że samo już to sformułowanie wydaje się absurdalne, ponieważ kultura sama w sobie jest kulturą życia i tylko nie-kultura może być „kulturą śmierci”.

\section{Nihilistyczne veto}

Nie sposób mówić o „kulturze śmierci”, nie odwołując się do tradycji nietzscheańskiej. Nie sposób też nie zauważyć, że postulowane na jej gruncie "przewartościowanie wartości” faktycznie zakłada radykalne odrzucenie wartości najwyższych. W tym przewartościowaniu bowiem wartości te dewaluują się. Stąd nie mamy żadnego prawa, aby w odniesieniu do świata rzeczy wyznaczyć jakieś „poza”, które by je wyzwoliło. Złączenie metafory morza i statku z myślą F. Nietzschego - „Bóg umarł - otwarło się morze”, a zatem: „na okręty filozofowie” - uruchamia dla dyskursu humanistycznego niespotykane spectrum możliwości poznawczych ${ }^{17}$. Jedna $\mathrm{z}$ nich jawi się poprzez odwołanie choćby do cytowanych wcześniej myślicieli Pascala i Kierkegaarda - ale także Josepha Conrada. W zderzeniu tym głębia myśli autora Zwierciadła morza poraża, w przeciwieństwie do refleksji Nietzschego, mimo wyrafinowania filozoficznego tej ostatniej18.

${ }^{15} \mathrm{H}$. Jonas, Zasada odpowiedzialności. Etyka dla cywilizacji technologicznej, tłum. M. Klimowicz, Kraków 1996.

16 Szerzej zob. H. Ciążela, Etyka odpowiedzialności Hansa Jonasa a "trwaty i zrównoważony rozwój" (Imperatywy i dylematy), „Problemy Ekorozwoju” 2006, vol. 1, nr 2.

17 F. Nietzsche, Wiedza radosna, tłum. L. Staff, „Dzieła Fryderyka Nietzschego”, t. 6, Warszawa 1906-1907, s. 288 i 234.

18 Interesująco na ten temat pisze M. Pacukiewicz w książce Dyskurs antropologiczny w pisarstwie Josepha Conrada, Kraków 2008; szczególnie s. 25-26. 
Interesujący nas Brague, aby zrozumieć współczesne myślenie w parametrach „kultury śmierci”, drąży tradycję nietzscheańską i dostrzega w niej cały potencjał dla rozwoju nihilizmu. Dookreślając ją przez etymologię słowa "nihilizm” (od łac. nihil - „nic"), rozważa ją jako drogę negatywną: drogę, która prowadzi do zawieszenia kultury transcendencji. Nietzsche bowiem walczy z centralną doktryną metafizyki klasycznej mówiącej o tożsamości i o "zamienności transcendentaliów” - Essere et Bonum convertuntur. Doktryna ta, określając relację między tym, co jest, a tym, co powinno być, jednocześnie zakłada, że warto, aby byt był - aby byt istniał. Natomiast teza o „zamienności transcendentaliów”, która dookreśla metafizyczną tezę ontologiczną, znajduje się już u filozofów greckich pod postacią prostego stwierdzenia: "To, co jest, jest dobre". Jej rozbudowanie wyrażone jest w sformułowaniu Arystotelesa: „Byt jest lepszy niż niebyt” czy Plotyna: „Byt jest identyczny z Dobrem". Metafizyka klasyczna, bazująca na tych tezach, otwiera możliwość uzgodnienia dwóch dróg filozofowania etykietowanych jako "Ateny” i „Jerozolima” („I widział Bóg, że było bardzo dobre” [Rdz 1,32]). Zgodność "Aten” $\mathrm{z}$ „Jerozolimą" uwidacznia się też w augustianizmie czy tomizmie ${ }^{19}$ - tym, co potwierdza identyczność Bytu i Dobra, jest pragnienie bycia, które istnieje we wszystkich rzeczach. Wszystko zależy zatem od wartości, którą należy przypisać temu pragnieniu. Metafizyka klasyczna łączy to z wolą człowieka, pojętą na sposób stoików - jako pragnienie oświecone przez rozum. Dobro jest tak (obiektywnie) wielkie, że człowiek jest dla niego gotów poświęcić nawet własne życie. Brague, rzutując na przywołaną tradycję metafizyki klasycznej nihilistyczną drogę, wyraźnie sugeruje, że ta ostatnia polega na powiedzeniu „nie” w stosunku do identyfikacji Bytu z Dobrem.

\section{Kochać żyć i kochać życie (aimer vivre et aimer la vie) ${ }^{20}$}

Odwołania Braguéa do metafizyki klasycznej pozwalają mu sukcesywnie zmierzać w stronę podjęcia kwestii aksjologicznych związanych z problemem uwieczniania. Filozof zauważa, że mówi się często „mi-

\footnotetext{
${ }^{19}$ Augustyn: „omne [...] quod est, in quantum est, est bonum” (De diversis quaestionibus); Tomasz z Akwinu: „Omne enim quod est, in quantum est ens, necesse est esse bonum. Esse namque suum unumquodque amat et conservari appetit. Signum autem est qiua contrapugnat unumquodque suae corruptioni" (Summa contra Gentiles, II, 41).

20 R. Brague, Les ancres..., op. cit., s. 71-74.
} 
łość życia", a tymczasem - według niego - należy odróżnić sformułowanie „kochać żyć” od „kochać życie”.

Punktem wyjścia tego rozróżnienia jest refleksja św. Augustyna. W Wyznaniach biskup Hippony zastanawia się nad słowami Jezusa, dlaczego „niektórzy nienawidzą światła" (J 3,20). Odpowiedź, jaka się tu nasuwa, odnosi się do rozumienia prawdy. Istnieją bowiem dwa jej rodzaje: ludzie, którzy „kochają prawdę, kiedy ona świeci, i [ci, którzy] jej nienawidzą, kiedy oskarża" (amant eam lucentem, oderunt eam redarguentem). Przy czym słowo „oskarża" jest trafne w tym sensie, $w$ jakim oznacza ono nie tylko to, że światło coś nam wypomina, ale także to, że światło, coraz bardziej wzrastając, pokonuje ciemności.

Prawda jest zatem światłem, które umożliwia nam poznanie rzeczy i panowanie nad nimi. Prawda zarówno pozwala nam na powrót do siebie, jak i wyciąga na jaw różne nasze ciemne sprawy i tajemnice. Dlatego pragniemy prawdy tego pierwszego rodzaju, ale uciekamy od drugiej.

Tymczasem jeśli rzeczywiście kochamy prawdę, to powinniśmy pragnąć także tej, która rzuci swe światło na nas samych. To rozróżnienie można odnieść także do natury. Lubimy ją jako źródło bogactw lub jako przyrodę. Nie lubimy jej ze względu na ograniczenia, jakie nakłada na nasze ciała.

To podwójne oblicze prawdy, wywołujące w nas pozytywne i negatywne nastawienie, dotyczy również stosunku do naszej „biologiczności”, a także naszego „czasowienia się". Lubimy przeszłość jako egzotyczny pejzaż dla turystyki historycznej, natomiast nie lubimy jej jako czegoś, co przypisuje nam konkretny wiek. Lubimy przyszłość jako przestrzeń utopijnych marzeń, nie lubimy jej jako czegoś, co wywołuje troskę zmuszającą nas do podjęcia pewnych trudnych decyzji.

Pozytywny i negatywny walor prawdy rzutujemy także na nasze życie. Stąd „kochać żyć” (aimer vivre) znaczy - żyć chętnie, cieszyć się życiem, kochać własne życie, kochać siebie samego. Znaczy to także: zgodzić się na to, co ma być, ponieważ jesteśmy - jakby powiedział Pascal - „zaokrętowani”.

Natomiast kochać życie (aimer la vie) znaczy kochać je, kiedy nie jest ono naszym; kochać je, kiedy od nas ono zależy; kochać życie - to dawać je. Na kanwie tego rozróżnienia rodzi się pytanie: dlaczego mamy to czynić?

\section{VII. „Silna" metafizyka}

Rozwiązanie kwestii „dlaczego mamy kochać życie?” nakłania nas do powrotu do Platona. W jego filozofii Dobro utożsamiane jest ze świa- 
tłem i jako takie sytuuje się ono poza Bytem: każdy byt otrzymuje to, co jest mu potrzebne do osiągnięcia swego dobra. Natomiast człowiek jako byt otrzymuje swoje dobro w wolności. Na bazie platońskich ustaleń rodzi się zatem kwestia więzi wolności z bytem i dobrem, a wraz z nią kwestia poświęcenia (le sacrifice).

Saloustios, neoplatonik z czasów Juliana Apostaty, w traktacie O bogach $i$ świecie pisze, że wystąpić może "pogarda istnienia (to einai) w celu [osiągnięcia] dobra (to agathon) u dusz szlachetnych (de valeur), kiedy spontanicznie (thelein) narażają się dla ojczyzny, dla przyjaciól, dla cnoty"21. A więc zdolność, jaką posiada człowiek, aby się poświęcić, wskazuje na to, że jest on gotów postawić Dobro ponad Bytem. Poświęcenie jest zatem czymś zupełnie innym niż samobójstwo, bowiem samobójstwo polega na zaprzeczeniu Bytu w sytuacji, w której nie widać, że stanowi on otwarcie na Dobro. W przypadku poświęcenia natomiast jest odwrotnie: istnieje Dobro, które możemy osiągnąć poza zwykłym istnieniem. Możemy zatem pragnąć tego Dobra, widzieć je. To znaczy, że jest ono w dyspozycji woli i może zostać osiągnięte poprzez wolę - że jest ono nam dostępne. Odniesienie do Dobra poprzez wolę jest wiarą, czyli rodzajem "ofiary intelektu" (por. logike latreia św. Pawła $[\operatorname{Rz} 12,1])$, a intelekt nie jest ofiarą, lecz tym, co składa ofiarę. To on ma złożyć ofiarę, a nie zaprzeczyć sobie, pogrążając się w głupocie. A zatem wiara jest odniesieniem do Dobra, Dobro zaś może być osiągnięte poprzez wolność. Brague'owi, gdy mówi o wierze, nie chodzi o to, by wskazywać na potrzebę religii w życiu społecznym (jak Le Maistre'owi czy Durkheimowi), jest on też daleki od twierdzenia, iż wiara stanowi źródło władzy i przemocy, jak to ujmowali ideolodzy oświecenia. Dla Brague'a jest to kwestia znacznie bardziej radykalna, ponieważ dotyczy relacji między religią a istnieniem człowieka na ziemi. Nie chodzi mu też o to, że kondycję człowieka rozpatrywać można jako animal sociale lub animal morale, przypisując człowiekowi przynależne mu cechy, lecz o rodzaj ludzki w całości jego wymiarów i procesu jego kształtowania - o pełnię jego życia.

Nietzsche pragnął, aby pojawił się Zaratustra, który powie: „Czynimy doświadczenie (Versuch) z prawdą! Być może ludzkość zniknie! Idźmy do tego! (wohlan!)"22. Dla Brague'a to pragnienie widoczne jest w myśleniu i działaniu wielu ludzi, którzy dzisiaj ryzykują swe życie, żywiąc przy tym irracjonalne przekonanie, że „jakoś to będzie”. W przeświadczeniu tym wi-

${ }^{21}$ Saloustios, Des dieux et du monde, Paris 1960, s. 9; cyt. za: R. Brague, Les ancres..., op. cit., s. $123-124$.

${ }^{22}$ F. Nietzsche, Fragment 25 [305], Kritische Studienausgabe, t. XI, cyt. za: R. Brague, Les ancres..., op. cit., s. 126. 
doczny jest jakiś rodzaj irracjonalnej wiary w opatrzność - tak jakby ludzkość dokonywała jakiegoś skoku na bungee, przy czym Brague nie jest pewien, czy lina została dobrze zahaczona. Widać wyraźnie, że w tym zakresie religia chrześcijańska zostawia więcej przestrzeni dla wolności człowieka i dla logiki jego działań.

Brague w rozmowie Rogerem-Polem Droitem powie, że jest w swoich poglądach radykalny, ponieważ tego wymaga przedmiot, jaki porusza:

Jeśli pragnie się osądzić wartość życia, rozwiązanie znajduje się w ostatecznej decyzji o identyczności bytu i dobra. [...] Ja nie mówię o sądzie odnośnie do życia osobistego, lecz odnośnie do tego życia, które mogę dać lub którego mogę odmówić i które dotyczy kogoś innego niż ja. Aby na to odpowiedzieć, trzeba tego, co nazywam „niebieskim zakotwiczeniem" [ancrage céleste] lub infrastrukturą metafizyczną. Nie ma potrzeby, aby w tej sprawie opierać się o jakąś określoną teologię, wystarczy, że będzie tu coś „boskiego”. Mało ważne, czy szuka się tego w naturze, w stylu stoickim, czy w nauczaniu religii. Lecz nauka [science] z tego właśnie punktu widzenia sprawia, że upadamy. Jeśli niebo jest puste, cóż wtedy znaczy kochać życie? Nie: kochać żyć, kochać moje życie, lecz naprawdę kochać życie. Ja [w nauce - przyp. M.J.] nie widzę [żadnego rozwiązania - przyp. M.J.] ${ }^{23}$.

Takie postawienie sprawy narzuca Rogerowi-Polowi Droitowi kolejne pytanie: czy humanizm niemetafizyczny wydaje się panu niemożliwy? W kontekście przekonań Brague'a odpowiedź jest łatwa do przewidzenia: dla niego humanizm niemetafizyczny jest pustą formułą - przy braku oparcia $\mathrm{w}$ Transcendencji, wszystkie sądy, które humanizm ów formułuje, są pozbawione należytej powagi. Książka Brague'a Les ancres dans le ciel uświadamia nam konieczność tego odniesienia, a zarazem szkicuje odpowiedź na kwestię uwieczniania się. Bez metafizycznej infrastruktury "człowiek jako podmiot na morzu" nie ma w niczym oparcia i nic nie usensawnia jego dramatycznej egzystencji. Mówienie o problemie uwieczniania się bez „zakotwiczenia w niebie" zdaje się pustą grą pojęciową.

\section{To Eternalize as a Mankind}

\section{Summary}

In this article author analyses the value on being itself as a basis and reason for prolongation of the mankind. Against some nihilistic and existentialist philosophers and writers who denied the value of life-giving, author refers to thoughts of Emmanuel Lévinas and Rémi Brague and shows that, like in the ancient and scholastic philosophy,

\footnotetext{
${ }^{23}$ R. Pol-Droit, ",Au nom de quoi faut-il se perpétuer?”, op. cit.
} 
we can find here the belief that Being is essentially connected with the Good itself. Neither science (as well as ideologies it evolves), nor pessimistic overview can give us such a powerful perspective to mankind's durability and its genuine value as a humanism, strengthened with religious faith, can do.

Słowa kluczowe: Rémi Brague, dawanie życia, wiara, nadzieja, egzystencjalizm

Keywords: Rémi Brague, life-giving, faith, hope, existentialism

DOI: $10.14746 /$ cbes.2016.15.3 